\title{
Structure of Hard And Soft Carapace Exoskeleton Biomaterial Through SEM-EDXRS at Various Stages of Development Scylla paramamosain Mud Crab
}

\author{
Haryo Triajie ${ }^{1,3}$, Sri Andayani ${ }^{2 *}$, Uun Yanuhar $^{2}$, Arning Wilujeng Ekawati ${ }^{2}$ \\ ${ }^{1}$ Postgraduate Student of Doctoral Program, Faculty of Fisheries and Marine Sciences, \\ Brawijaya University, Malang, Indonesia \\ ${ }^{2}$ Faculty of Fisheries and Marine Sciences, Brawijaya University, Malang, Indonesia \\ ${ }^{3}$ Faculty of Agricultural Trunojoyo Madura University, Bangkalan, Indonesia
}

Received: October 29, 2020. Revised: April 14, 2021. Accepted: May 9, 2021. Published: May 14, 2021.

\begin{abstract}
Crustacean carapace has various functions which can be seen from the composition of the biomaterial in it. Various concentrations of inorganic biomaterial elements were investigated from the hard carapace and the newly molted (soft-shelled) (Scylla paramamosain) with SEM-EDXRS (scanning electron microscopy-Energy Dispersive X-ray Spectrometer) technique. This study traced the composition of the inorganic elements of the premolt, postmolt, intermolt and soft (exuvium) crab hard carapace tissue of mangrove crabs from the point of view. Various stages of development. Important elements such as $\mathrm{C}, \mathrm{O} 2, \mathrm{Mg}, \mathrm{P}, \mathrm{Ca}, \mathrm{S}, \mathrm{Na}, \mathrm{Si}, \mathrm{Cl}$, and others, are reabsorbed from the carapace into the body tissues to fulfill further needs in soft-shelled crabs and are reused to some extent during formation new carapace. This study provides evidence that, inorganic elements in freshly molted soft carapace crabs are less common than hard carapace crabs.
\end{abstract}

Keywords-Carapace, Scylla paramamosain, inorganic, SEM-EDXRS

\section{INTRODUCTION}

Mangrove crab, Scylla sp. Is in great demand for consumption both in local and export markets because of its deliciousness. The high demand for exports in living conditions and the rising prices of fishery products have made mangrove crab cultivation a part of world interest. Soft carapace crab is a seafood that is highly sought after in international markets such as in Asia, Europe and America which has led to an increase in the production of mud crab which has made the price higher compared to other seafood [1], [2].

In part of their life, mangrove crabs are inhabitants of the high seas, then they immigrate to the brackish water environment of mangrove forests during the post larvae stage [3], [4] and grow quickly mature and mature sex [5]. This species inhabits deep seas as well as brackish waters with muddy or sandy bottoms [6] and classified as a euryhaline species [7] so that it can live in 2-30 ppt salinity waters [8][10]. Based on the carapace changing cycle, crustaceans are divided into five stages (A-E), with further subdivisions in each stage. The postmolt period corresponds to stages A1, A2, B1, $\mathrm{B} 2, \mathrm{C} 1, \mathrm{C} 2$, and $\mathrm{C} 3$; the intermolt is the $\mathrm{C} 4$ stage; premolt consists of stages Do, D1 ', D1' ', D1' ", D2, D3, and D4; and ecdysis or molting is stage $\mathrm{E}$ [11].

Carapace replacement is a biological process in all crustacean species periodically in which the old exoskeleton (exuvium) is released and the new one is formed immediately so that in this process there is an increase in growth or weight [9], [12]-[15]. After the change of carapace, the exoskeleton (exuvium) of crabs becomes smooth or soft due to its soft (spongy) muscles with a thin membrane and accounts for 30 $38 \%$ of the body weight of freshly molted soft carapace crabs, so it appears that more than $60 \%$ of the crab's body is meat [16][18]. Towards and when the carapace change takes place, individual crab weight decreases as a result of reduced feeding activity. During the postmolt phase, it will be followed by a relatively constant increase in weight until the next carapace change period [19]-[23]. During the process of carapace replacement, a series of physiological and biochemical changes occur in which some trace elements are absorbed from the old carapace and from the surrounding water through regulation by body tissues and then stored in the gastroliths disk [24] - [26] and then through the excretion process. Reused when forming 
new carapace and biomineralization of hardening of the carapace [27] - [31].

Crustaceans are known to be able to regulate the total amount of certain chemicals from the appearance of the elements during the metabolic process [32], [33]. In general the variation pattern is well known that $\mathrm{Ca}, \mathrm{Mg}$ and $\mathrm{P}$ during the moulting phase of the calcification process [34], [35]. There is still little information about the elements in the carapace at various stages of the development of $S$. paramamosain mangrove crabs, so research is needed to determine changes in inorganic elements in soft carapace (molting) and hard carapace premolt, postmolt and intermolt in evaluating and providing evidence of inorganic elements. In freshly molted soft carapace crabs are of less variety than hard carapace crabs in the biomineralization process. The benefits of this study will provide information about the bio-regulation of inorganic elements during developmental stages and during the process of replacing old exoskeletons Mangrove crabs from the mangrove forests of Pulokerto Village, Kraton District, Pasuruan Regency, East Java Province

\section{MATERIAL AND METHOD}

Mangrove crabs of $S$. paramamosain were obtained from the mangrove forest area of Pulokerto village, Kraton district, Pasuruan regency, East Java province and then kept in plastic boxes in which there is one each to avoid cannibalism and be able to adjust to normal maintenance pond water. Mud crabs are fed trash fish in the morning and evening purchased directly from local fishermen. Mud crabs are allowed to molt in natural conditions in rearing boxes and are always monitored in the morning, afternoon and evening every day. When you get the crab who had been molted, they were collected on the same day along with the respective old exocuticle and the molts were sacrificed for inorganic analysis. Likewise, crabs that experienced premolt and postmolt from the same environment were collected and stored and then sacrificed after 14 days to compare the concentrations of soft and hard carapace elements. All crabs taken for analysis came from both male and female adult groups with a weight range of 71-90 $\pm 0.8 \mathrm{~g}$ and a carapace width of $6.0-7.0 \pm 0.7 \mathrm{~cm}$. Biometric details of crabs used for analysis are presented in Table 1.

Mud crab samples selected for analysis were grouped separately based on sex, and the stages of its life cycle from premolt, postmot, intermolt to molt (exuvium). Each crab in these groups was then measured for carapace width and body weight. This was done to make it easier to evaluate the presence of their respective elements. The crab samples were then thoroughly washed in deionized water. The premolt, postmolt, intermolt and exuvium phases of hard carapace from freshly molted soft carapace were also taken for analysis. The hard carapace and exuvium samples were dried under the sun and then each was cut into small pieces $0.3 \pm 0.2 \mathrm{~mm}$ using sterile scissors so that they would not be contaminated for further analysis using Scanning Electron Microscope (SEM) - Energy Dispersive X-ray Spectrometer. SEM-EDXS can analyze powerful materials by classifying objects specifically by considering chemical and physical properties and simultaneously providing information on topography, morphology, and elemental composition of objects. Besides, the advantages of being able to detect and analyze surface fractures, provide information in microstructure, examine contamination of a surface, reveal spatial variations in chemical composition, provide qualitative chemical analysis, and identify crystal structure [24] in the calcification process of cuticles in the postmolt and premolt (D3) [36] blue crab, Callinectes sapidus and cuticle mineralization processes in terrestrial isopods Armadillidium vulgare and Porcellio scaber [37], as well as characterization of minerals accumulated in tissues [38].

\section{Instrumentation}

Scanning Electron Microscope (SEM) TM 3000 Hitachi with Swift Energy Dispersive 3000 X-Ray Microanalysis. The direct Spectrometer automatically connects to the PC in the circuit by simply plugging it into the computer's USB port. This tool has advantages where the sample to be analyzed does not have to be small in size so that large samples no longer need to be cut and do not require coating as well does not require special specimen preparation like other SEM tools, so the operation is very easy to use to obtain realistic images with good depth of focus and higher magnification as well to determine the composition of the elements.

Hitachi's SEM-EDX-Ray TM 3000 in the elemental specimen analysis process is able to measure the sample density maximum diameter $25 \mathrm{~mm}$, magnification from 15 to 30,000 times, has a resolution of $30 \mathrm{~nm}, 15-\mathrm{kV}$ observation mode and energy-dispersive X-ray spectrometer (EDXS), uses a highperformance SDD detector module and the activation time is only about three minutes on current power (AC) 100-240 V.

\section{RESULTS AND DISCUSSION}

SEM-EDXS managed to find carbon (C), oxygen $(\mathrm{O} 2)$, magnesium $(\mathrm{Mg})$, and posphorus $(\mathrm{P})$ as the main component of carapace, sodium $(\mathrm{Na})$, chlorine $(\mathrm{Cl})$ and silicon $(\mathrm{Si})$, sulfur $(\mathrm{S})$, bromine $(\mathrm{Br})$, aluminum $(\mathrm{Al})$, potassium $(\mathrm{K})$, iron $(\mathrm{Fe})$, and copper $(\mathrm{Cu})$ in small quantities. Concentrations of 14 constituents of freshly molted exuvium hard and soft carapace in $S$. paramamosain mangrove crabs are presented in Table 2.

Both carbon $(\mathrm{C})$ and oxygen $(\mathrm{O} 2)$ are the largest elements in all carapace conditions, both hard and soft (exuvium) in both male and female crab sexes. Of the 14 elements found in the carapace, 11 elements are hard carapace in the postmolt stage of male crab, consisting of carbon (C), oxygen (O2), 
magnesium $(\mathrm{Mg})$, phosphorus $(\mathrm{P})$, and calcium sulfur $(\mathrm{S})$, Silicon $(\mathrm{Si})$, clorine $(\mathrm{Cl})$, aluminum $(\mathrm{Al})$, iron $(\mathrm{Fe})$ and copper $(\mathrm{Cu})$. This also occurs in 10 female crab postmolt in the form of carbon $(\mathrm{C})$, oxygen $(\mathrm{O} 2)$, magnesium $(\mathrm{Mg})$, phosphorus $(\mathrm{P})$, calcium $(\mathrm{Ca})$, sodium $(\mathrm{Na})$, Silicon $(\mathrm{Si})$, clorine $(\mathrm{Cl})$. ), bromine $(\mathrm{Br})$, aluminum $(\mathrm{Al})$, and potassium $(\mathrm{K})$. For the second most, there is a premolt stage in both sexes.

The elements carbon $(\mathrm{C})$, oxygen $(\mathrm{O} 2)$, magnesium $(\mathrm{Mg})$, phosphorus $(\mathrm{P})$, calcium $(\mathrm{Ca})$ and clorine $(\mathrm{Cl})$ are almost all found in hard and soft carapaces (exuvium). These results have also been reported that $\mathrm{Ca}$ and $\mathrm{Mg}$ are the main elements in the hard and soft carapace of mangrove crabs [39]. The carbon (C) element in both sexes is relatively higher at the time of molting and after passing through it the carbon (C) returns to decline. The highest amount of weight of carbon (C) occurs when crab molting or on soft carapace (exuvium)male crab amounting to $55.32 \pm 0.02 \mathrm{wt} \%$ and $57.15 \pm 0.02 \mathrm{wt} \%$ in females compared to the premolt, postmolt or intermolt stages (Figures 1 and 2). The postmolt stage has the second highest carbon element weight (C) under the molting stage in all sexes of $45.38 \pm 0.05$ wt $\%$ in males and $52.86 \pm 0.03 \mathrm{wt} \%$ in females, while the lowest in both sexes looks the same in the premolt stage of $17.26 \pm 0.08 \mathrm{wt} \%$ in males and $24.98 \pm 0.02 \mathrm{wt} \%$ in females. This condition concludes that the element $\mathrm{C}$ is absorbed by the soft carapace tissue during the molting process and decreases in number when it enters the next phases such as the premolt, intermolt and premolt phases.

The weight of the element oxygen (O2) contained in the carapace was the highest in the premolt stage and was relatively the same in both sexes, namely $55.01 \pm 0.22 \mathrm{wt} \%$ in males and $55.51 \pm 0.01 \mathrm{wt} \%$ in females. Oxygen $(\mathrm{O} 2)$ tends to decrease in the hard carapace of the postmolt stage in both sexes by 37.29 $\pm 0.14 \mathrm{wt} \%$ in males and $31.51 \pm 0.09 \mathrm{wt} \%$ in females and increases in the intermolt stage in male or female crab carapace. In the carapace or molting stage, the weight of the element $\mathrm{O} 2$ is relatively slightly lower than that of the premolt stage, $\mathrm{O} 2$ in the male carapace in all types of carapace from premolt to molting has a relatively higher weight than $\mathrm{O} 2$ in female carapace. This element of $\mathrm{O} 2$ is thought to always be available in the carapace, the number of which fluctuates depending on the phases in the molting cycle. There have been no studies reported on the element $\mathrm{O} 2$ in relation to carapace turnover, so it is difficult to provide a convincing statement regarding its relationship to the carapace turnover cycle in crustaceans.

Magnesium $(\mathrm{Mg})$ is also an element found in all types of hard and soft carapace, both male and female crabs. As a major constituent of exoskeleton crustacean, it is reabsorbed during the premolt period [40]. This element in the two sexes of crabs has a relative weight that is not much different. The highest weight of the element $\mathrm{Mg}$ is found in the hard carapace of male and female crabs at the premolt stage. This change in $\mathrm{Mg}$ is part of the calcification process. The results of this study are in accordance with the statement [41] that in prawn, the highest proportion of $\mathrm{Mg}$ was found in the premolt phase carapace[42], early postmolt white prawn Penueus indicus. The weight of $\mathrm{Mg}$ in the male hard carapace was higher than that of the female, respectively $1.58 \pm 0.60 \mathrm{wt} \%$ and $1.48 \pm 0.34 \mathrm{wt} \%$, while the lowest in both sexes occurred in the molting (exuvium) stage where $\mathrm{Mg}$ in the male exuvium was higher than the female, which was $0.44 \pm 0.03 \mathrm{wt} \%$ and $0.38 \pm 0.07 \mathrm{wt} \%$ in females.

The combination of $\mathrm{Mg}$ and Asp-rich compounds triggered the basic process of crystallization in the crustacean carapace biomineralization [43]. Crabs have a tendency to produce $\mathrm{Mg}$ in calcite as a way of demonstrating strength in finding the mechanical balance of calcite while limiting its solubility in seawater [44],[45] found that $\mathrm{Mg}$ levels in Penaeus californiensis were stable 12 to 24 hours after molting. [46] states that $\mathrm{Mg}$ is required at higher concentrations for proper functioning of the molting process. This suggests that there may also have been chemical or possibly biological (active) deposition of $\mathrm{Mg}$ in the old carapace. Such removal of magnesium, even if it happens to be beneficial, because $\mathrm{Mg}$ continuously enters the body and has to be excreted [47]. The presence of the element phosphorus (P) is present in all phase in male crabs compared to females. The highest weight of $\mathrm{P}$ elements in both sexes is found in exuvium or when the carapace is soft, where the male is $1.45 \pm 0.07 \mathrm{wt} \%$ and the female is $1.28 \pm 0.11 \mathrm{wt} \%$. Especially in the postmolt phase, element $\mathrm{P}$ has the lowest weight of all the phases in both sexes, even in females, this element is not found. This element eventually increases in number again in the intermolt phase and then peaks in molting and drops when it is in the postmolt phase. Enhancement inorganic phosphate in the blood when the crab is in the premoult phase can increase the osmotic pressure by 0 - 2 percent [48].

Calcium $(\mathrm{Ca})$ is seen as the third most abundant element and is present in all stages of the life cycle of crabs, both male and female. The weight of $\mathrm{Ca}$ in carapace in male crabs has an average weight greater than that of females. Ca element in premolt in both sexes was seen to have the highest weight of all life phases of crab at $23.60 \pm 0.70 \mathrm{wt} \%$ in males and $14.30 \pm$ $0.07 \mathrm{wt} \%$ in females. During the intermoult period, the exoskeleton the maximally. When crabs undergo carapace change or molting, the weight of $\mathrm{Ca}$ in the exuvium of both sexes is seen to be the lowest, namely $2.38 \pm 0.33 \mathrm{wt} \%$ in males and $2.26 \pm 0.05 \mathrm{wt} \%$ in females, and then it increases again at postmolt. This change in $\mathrm{Ca}$ is part of the calcification process. These data show some evidence that $\mathrm{Ca}$ ions and bicarbonate ion reabsorbed from old carapace and temporarily stored in the gastroliths on both sides of the inner belly happened before and after they're actually experiencing replacement of old carapace or molting [49], [50]. This result is in accordance with the statement [51] who reported that $\mathrm{Ca}$ was lower in the newly replaced carapace (Carcinus maenas) than in the premolt stage. 
The crustacean exoskeleton contains a large number of inorganic calcium carbonate compounds, which can reduce flexibility and elasticity so that this hardness interferes with the molting process.

Therefore crustaceans have the ability to reduce the level of $\mathrm{CaCO} 3$ content in the cuticles by being reabsorbed and stored before molting to increase flexibility where temporary storage of calcium carbonate is controlled by special organs [52], [53]. The location of Ca storage depends on the crustacean species [54], the terrestrial crustacean Orchestia cavimana is stored in a midgut organ called the ceca [55], Porcellio scaber and Armadillidium vulgare in the sternal area [56], as well as the hepatopancreas or hemolymph [34].

Crustaceans have a high calcium content, which is located in the skeleton because calcium carbonate and $\mathrm{Ca}$ are generally cations that are abundant in the body [34]. Ca metabolism is related to life and reproductive strategies [57]. Ca concentrations generally vary in each aquatic ecosystem [40], so that low $\mathrm{Ca}$ concentrations can limit growth and production [58]. Therefore, a sufficient amount of elemental $\mathrm{Ca}$ is required after each carapace replacement [59]. The imperfection of the calcification process on the soft carapace causes the freshwater crustacean organisms to become cannibalistic [60] and external injuries [61].

Calcium is the main inorganic component present in the carapace and exoskeleton [40], [55], and contains various biological functions (growth and molting) and also has an important structural role in crayfish [62]. The main sources of $\mathrm{Ca}$ in crustaceans and crayfish are water and nutrients containing $\mathrm{Ca}$ ions [58], [63], [64]. In freshwater crayfish $\mathrm{Ca}$ is needed for the new carapace hardening process after molting from water or feed [65]. Calcium $(\mathrm{Ca})$ is also considered as one of the most important minerals [66] and required for normal growth and development of bones and various physiological processes of aquatic organisms [67]. All aquatic organisms require inorganic elements or minerals for their normal life processes [68] and is an important macro element for ecophysiological activity [69], [70].

Water environmental factors such as water temperature, dissolved oxygen, $\mathrm{pH}$, calcium and magnesium play an important role in the growth and survival of crayfish [64], [71], [72], explained that the survival, growth and turnover of the carapace are influenced by calcium, and lobsters that are fed with calcium with added carbonate will have a larger and heavier gastrolith when the carapace is soft because after that calcium carbonate is used for carapace formation rather than being fed in it calcium chloride.

The element chlorine $(\mathrm{Cl})$ is found in all genders but only in the premolt, postmolt and intermolt phases, while in the molting phase in exuvium this element is not found. Like the other eight elements, including sulfur $(\mathrm{S})$, silicon ( $\mathrm{Si})$, bromine $(\mathrm{Br})$, aluminum $(\mathrm{Al})$, potassium $(\mathrm{K})$, iron $(\mathrm{Fe})$ and copper $(\mathrm{Cu})$ are found in hard carapaces but are not found in soft carapace (exuvium) of the mangrove crab $S$. paramamosain. The eight elements is thought to have been absorbed from the water that is around it after the replacement of the old carapace which is regulated in the body's tissues during the excretion process or is used during the process of forming new carapaces and also indicates that these elements may have been excreted during the replacement of old carapace.

$\mathrm{Br}$ is an element that also accumulates in crustaceans [73], which consists of non-calcified Br-rich tissue containing about $1 \% \mathrm{Br}$. This $\mathrm{Br}$ showed higher resistance to fracture and hardness compared to calcified cuticles and was found to bind to the phenyl ring to form bromotyrosine which attributed increased hardness and stiffness to the promotion of Br-induced protein crosslinking and / or when a higher Br mass [74]. $\mathrm{Cu}$ elements in this study were only found in the postmolt and premolt stages of crab hard carapace in both sexes. This result differs from research [75], [76] [75] which states that $\mathrm{Cu}$ is present in the intermolt phase and in the hemolymph and hepatopancreas [77].

In this study also found elements of $\mathrm{Al}, \mathrm{K}$, and $\mathrm{Fe}$ which were only found in the postmolt and premolt stages of crab hard carapace in both sexes. It is possible that these elements are arranged after the carapace change process occurs and there has been no previous research that has reported these elements from crustaceans in relation to carapace turnover, so it is difficult to provide a convincing statement of their relationship to the carapace change cycle.

\section{CONCLUSION}

The study shows the technique's effectiveness in analyzing the biological material of carapace tissue samples, thus opening up opportunities for further broader studies.. Inorganic biomaterials that are present especially in the molting phase or when the crab changes to a new carapace with a soft carapace (exuvium), both male and female have biomaterial elements that are relatively different from all types of hard carapace at the premolt, postmolt and intermolt stages. Comparing the elements in the hard and soft carapace (exuvium) of male and female $S$. paramamosain crabs (Figures 1 and 2) shows that $\mathrm{Mg}$ in the premolt stage to molt is the second-highest concentration after $\mathrm{Ca}$, and then both drastically decrease when the molt stage. Towards postmolt. It is clear that $\mathrm{Ca}, \mathrm{Mg}$, and other constituents are also partially reabsorbed [78], [79] from the hard (old) carapace into the tissues of the body as a necessity when the molting process takes place and is further used for the formation. As well as new carapace hardening [50], [80], [81] to some extent [82] - [84] in the biomineralization process [34]. This condition can be concluded clearly that the presence of elemental concentrations in the carapace will be affected when the crab enters the new carapace replacement stage (molt). 


\section{ACKNOWLEDGEMENTS}

The author would like to thank the Directorate General of Research and Development Strengthening. The Ministry of Research, Technology and Higher Education (Kemenristek DIKTI) of the Republic of Indonesia which has provided doctoral grants. Furthermore, thanks to the promoters and copromoters who guided this research from the preparation of the proposal to the writing of the research report.

\section{References}

[1] M. M. Rahman et al., "Assessment of mud crab fattening and culture practices in coastal bangladesh: Understanding the current technologies and development perspectives," AACL Bioflux, vol. 13, no. 2, pp. 582-596, 2020.

[2] D. B. Hungria, C. P. dos Santos Tavares, L. Â. Pereira, U. de Assis Teixeira da Silva, and A. Ostrensky, "Global status of production and commercialization of soft-shell crabs," Aquaculture International. 2017, doi: 10.1007/s10499-017-0183-5.

[3] J. H. Primavera, Mangroves as mud crab habitats. 2017.

[4] A. Leoville, R. Lagarde, H. Grondin, L. Faivre, E. Rasoanirina, and N. Teichert, "Influence of environmental conditions on the distribution of burrows of the mud crab, Scylla serrata, in a fringing mangrove ecosystem," Reg. Stud. Mar. Sci., vol. 43, p. 101684, Mar. 2021, doi: 10.1016/j.rsma.2021.101684.

[5] H. Alberts-Hubatsch, S. Y. Lee, J. O. Meynecke, K. Diele, I. Nordhaus, and M. Wolff, "Life-history, movement, and habitat use of Scylla serrata (Decapoda, Portunidae): current knowledge and future challenges," Hydrobiologia, vol. 763, no. 1, pp. 5-21, 2016, doi: 10.1007/s10750-015-2393-z.

[6] J. Bir, S. S. Islam, W. Sabbir, M. R. Islam, and K. A. Huq, "Ecology and reproductive biology of Mud Crab Scylla spp: A study of commercial mud crab in Bangladesh," Int. J. Acad. Res. Dev., vol. 5, no. 2, pp. 1-7, 2020.

[7] Y. Zhang et al., "MRNA profile provides novel insights into stress adaptation in mud crab megalopa, Scylla paramamosain after salinity stress," BMC Genomics, vol. 21, no. 1, pp. 1-16, 2020, doi: 10.1186/s12864-02006965-5.

[8] C. N. Glaspie, R. D. Seitz, M. B. Ogburn, C. F. Dungan, and A. H. Hines, "Impacts of habitat, predators, recruitment, and disease on soft-shell clams Mya arenaria and stout razor clams Tagelus plebeius in Chesapeake Bay," Mar. Ecol. Prog. Ser., 2018, doi: 10.3354/meps 12706.

[9] M. I. Spitznagel, H. J. Small, J. A. Lively, J. D. Shields, and E. J. Schott, "Investigating risk factors for mortality and reovirus infection in aquaculture production of softshell blue crabs (Callinectes sapidus)," Aquaculture, 2019, doi: 10.1016/j.aquaculture.2018.12.051.

[10] N. Thirunavukkarasu, S. A. N. C, and A. A. Shanmugam, "Larval rearing and seed production of mud crab Scylla tranquebarica ( Fabricius , 1798 )," Int. J. Fish. Aquat. Stud. 2014; 2(2) 19-25 Chennai-600 039, Tamilnadu,
India. E, 2014.

[11] P. Drach et al., "SUR LA MÉTHODE DE DÉTERMINATION DES STADES D ' INTERMUE ET SON APPLICATION GÉNÉRALE AUX CRUSTACÉS Pierre Drach, Catherine Tchernigovtzeff To cite this version : HAL Id : hal-02951622," 2020.

[12] M. Asmat-Ullah et al., "Induced mating of newly molted females of orange mud crab, Scylla olivacea (Herbst, 1796), in captivity," Aquaculture, 2021, doi: 10.1016/j.aquaculture.2020.736159.

[13] C. P. S. Tavares, U. A. T. DA SILVA, L. Â. Pereira, and A. Ostrensky, "Evaluation of different induced molting methods in callinectes ornatus (Crustacea, decapoda, portunidae) as a tool for the commercial production of soft-shell crabs," An. Acad. Bras. Cienc., vol. 93, no. 2, pp. 1-14, 2021, doi: 10.1590/0001-3765202120190580.

[14] P. Sukardi, N. A. Prayogo, T. Harisam, and A. Sudaryono, "Effect of eyestalk-ablation and differences salinity in rearing pond on molting speed of Scylla serrata," in AIP Conference Proceedings, Apr. 2019, vol. 2094, doi: 10.1063/1.5097498.

[15] A. "Rusty" Gaudé and J. A. Anderson, "Soft shell crab shedding systems," no. 4306, pp. 1-6, 2011.

[16] D. O. Mirera and A. Mtile, "A preliminary study on the response of mangrove mud crab (Scylla serrata) to different feed types under drive-in cage culture system," J. Ecol. Nat. Environ., 2009.

[17] J. Gong et al., "Ecdysone receptor in the mud crab Scylla paramamosain: A possible role in promoting ovarian development," J. Endocrinol., vol. 224, no. 3, pp. 273287, 2015, doi: 10.1530/JOE-14-0526.

[18] M. S. Rahman, M. M. H. Kazal, and S. J. Rayhan, "Impacts of the training of mud crab farmers: An adaptation strategy to cope with salinity intrusion in Bangladesh," Mar. Policy, vol. 120, Oct. 2020, doi: 10.1016/j.marpol.2020.104159.

[19] Q. Zhan et al., "Effects of dietary carbohydrate levels on growth, body composition, and gene expression of key enzymes involved in hepatopancreas metabolism in mud crab Scylla paramamosain," Aquaculture, 2020, doi: 10.1016/j.aquaculture.2020.735638.

[20] M. N. Azra, C. P. D. S. Tavares, A. B. Abol-Munafi, and M. Ikhwanuddin, "Growth rate and fatty acid composition of orange mud crab instars, Scylla olivacea, reared at different temperatures," Egypt. J. Aquat. Res., vol. 46, no. 1, pp. 97-102, Mar. 2020, doi: 10.1016/j.ejar.2019.11.006.

[21] S. N. Fatihah, H. T. Julin, and C. A. Chen, "Survival, growth, and molting frequency of mud crab scylla tranquebarica juveniles at different shelter conditions," AACL Bioflux, vol. 10, no. 6, pp. 1581-1589, Dec. 2017.

[22] M. Ikhwanuddin, A. Amin-Safwan, N. Hasyima-Ismail, and M. N. Azra, "Dataset on body weight, carapace width increment and growth band count of mud crabs, Scylla olivacea," Data Br., vol. 26, p. 104477, Oct. 2019, doi: 10.1016/j.dib.2019.104477.

[23] M. H. Holme, P. C. Southgate, and C. Zeng, "Survival, development and growth response of mud crab, Scylla serrata, megalopae fed semi-purified diets containing various fish oil:corn oil ratios," Aquaculture, vol. 269, no. 
1-4, pp. 427-435, Sep. 2007, doi: 10.1016/j.aquaculture.2007.05.024.

[24] H. Nagasawa, "The crustacean cuticle: Structure, composition and mineralization," Front. Biosci. - Elit., vol. 4 E, no. 2, pp. 711-720, 2012, doi: 10.2741/E412.

[25] H. Nagasawa, "The molecular mechanism of calcification in aquatic organisms," Biosci. Biotechnol. Biochem., vol. 77, no. 10, pp. 1991-1996, 2013, doi: $10.1271 / \mathrm{bbb} .130464$.

[26] C. J. Hyde, A. Elizur, and T. Ventura, "The crustacean ecdysone cassette: A gatekeeper for molt and metamorphosis," J. Steroid Biochem. Mol. Biol., vol. 185, pp. 172-183, 2019, doi: 10.1016/j.jsbmb.2018.08.012.

[27] P. Y. Chen, A. Y. M. Lin, J. McKittrick, and M. A. Meyers, "Structure and mechanical properties of crab exoskeletons," Acta Biomater., vol. 4, no. 3, pp. 587-596, 2008, doi: 10.1016/j.actbio.2007.12.010.

[28] F. Boßelmann, P. Romano, H. Fabritius, D. Raabe, and M. Epple, "The composition of the exoskeleton of two crustacea: The American lobster Homarus americanus and the edible crab Cancer pagurus," Thermochim. Acta, vol. 463, no. 1-2, pp. 65-68, 2007, doi: 10.1016/j.tca.2007.07.018.

[29] F. Neues, S. Hild, M. Epple, O. Marti, and A. Ziegler, "Amorphous and crystalline calcium carbonate distribution in the tergite cuticle of moulting Porcellio scaber (Isopoda, Crustacea)," J. Struct. Biol., vol. 175, no. 1, pp. 10-20, 2011, doi: 10.1016/j.jsb.2011.03.019.

[30] B. Y. D. S. Neufeld and J. N. Cameron, "Postmoult Uptake of Calcium by the Blue Crab (Callinectes Sapidus) in Water of low Salinity," J. Exp. Biol., vol. 171, no. 1, pp. 283-299, 1992.

[31] S. A. Shaked, S. Abehsera, T. Levy, V. Chalifa-Caspi, and A. Sagi, "From sporadic single genes to a broader transcriptomic approach: Insights into the formation of the biomineralized exoskeleton in decapod crustaceans," J. Struct. Biol., vol. 212, no. 2, p. 107612, 2020, doi: 10.1016/j.jsb.2020.107612.

[32] N. M. Amin, W. B. W. Omar, N. H. A. Kadir, N. S. M. Razali, F. N. A. M. Ubaidillah, and M. Ikhwanuddin, "Analysis of trace metals ( $\mathrm{Ni}, \mathrm{Cu}, \mathrm{And} \mathrm{Zn}$ ) in water, mud and various tissues of Mud Crab, Scylla Olivacea from Setiu Wetlands, Terengganu, Malaysia," J. Sustain. Sci. Manag., 2018

[33] P. S. Rainbow, "Accumulation of $\mathrm{Zn}, \mathrm{Cu}$ and $\mathrm{Cd}$ by crabs and barnacles," Estuar. Coast. Shelf Sci., vol. 21, no. 5, pp. 669-686, 1985, doi: 10.1016/0272-7714(85)90065-4.

[34] P. GREENAWAY, "Calcium Balance and Moulting in the Crustacea," Biol. Rev., vol. 60, no. 3, pp. 425-454, 1985, doi: 10.1111/j.1469-185x.1985.tb00424.x.

[35] Y. Lei et al., "Effect of dietary phosphorus on growth performance, body composition, antioxidant activities and lipid metabolism of juvenile Chinese mitten crab (Eriocheir sinensis)," Aquaculture, vol. 531, no. May 2020, p. 735856, 2021, doi: 10.1016/j.aquaculture.2020.735856.

[36] R. D. Roer and R. M. Dillaman, "The initiation and early stages of postmolt mineralization in the blue crab, Callinectes sapidus," Front. Mar. Sci., vol. 5, no. MAY, pp. 1-8, 2018, doi: 10.3389/fmars.2018.00151.
[37] S. Hild, O. Marti, and A. Ziegler, "Spatial distribution of calcite and amorphous calcium carbonate in the cuticle of the terrestrial crustaceans Porcellio scaber and Armadillidium vulgare," J. Struct. Biol., vol. 163, no. 1, pp. 100-108, 2008, doi: 10.1016/j.jsb.2008.04.010.

[38] M. Scimeca, S. Bischetti, H. K. Lamsira, R. Bonfiglio, and E. Bonanno, "Energy dispersive X-ray (EDX) microanalysis: A powerful tool in biomedical research and diagnosis," Eur. J. Histochem., vol. 62, no. 1, pp. 8999, 2018, doi: 10.4081/ejh.2018.2841.

[39] S. Benjakul and N. Sutthipan, "Comparative study on chemical composition, thermal properties and microstructure between the muscle of hard shell and soft shell mud crabs," Food Chem., vol. 112, no. 3, pp. 627633, Feb. 2009, doi: 10.1016/j.foodchem.2008.06.019.

[40] P. Greenaway, "Calcium and Magnesium Balance during Molting in Land Crabs," J. Crustac. Biol., vol. 13, no. 2, p. 191, 1993, doi: 10.2307/1548969.

[41] J. F. Wickins, "The effect of reduced $\mathrm{pH}$ on carapace calcium, strontium and magnesium levels in rapidly growing prawns (Penaeus monodon fabricius)," Aquaculture, vol. 41, no. 1, pp. 49-60, 1984, doi: 10.1016/0044-8486(84)90389-2.

[42] K. K. Vijayan and A. D. Diwan, "Fluctuations in Ca, Mg and $\mathrm{P}$ levels in the hemolymph, muscle, midgut gland and exoskeleton during the moult cycle of the Indian white prawn, Penaeus indicus (Decapoda: Penaeidae)," Comp. Biochem. Physiol. - A Physiol., 1996, doi: 10.1016/03009629(95)02096-9.

[43] J. Tao, D. Zhou, Z. Zhang, R. Xu, and R. Tang, "Magnesium-aspartate-based crystallization switch inspired from shell molt of crustacean," Proc. Natl. Acad. Sci. U. S. A., vol. 106, no. 52, pp. 22096-22101, 2009, doi: $10.1073 /$ pnas.0909040106.

[44] A. M. Fay and A. M. Smith, "In a pinch: Skeletal carbonate mineralogy of crabs (Arthropoda: Crustacea: Decapoda)," Palaeogeogr. Palaeoclimatol. Palaeoecol., vol. 565, p. 110219, Mar. 2021, doi: 10.1016/j.palaeo.2021.110219.

[45] J. V. Huner, L. B. Colvin, and B. L. Reid, "Whole-body calcium, magnesium and phosphorous levels of the California brown shrimp, Penaeus californiensis (Decapoda: Penaeidae) as functions of molt stage," Comp. Biochem. Physiol. -- Part A Physiol., vol. 64, no. 1, pp. 33-36, 1979, doi: 10.1016/0300-9629(79)90426-2.

[46] L. A. Fieber and P. L. Lutz, “ Magnesium and calcium metabolism during molting in the freshwater prawn Macrobrachium rosenbergii ," Can. J. Zool., vol. 63, no. 5, pp. 1120-1124, May 1985, doi: 10.1139/z85-169.

[47] L. Hagerman, "Haemocyanin concentration of juvenile lobsters (Homarus gammarus) in relation to moulting cycle and feeding conditions," Mar. Biol., vol. 77, no. 1, pp. 11-17, 1983, doi: 10.1007/BF00393205.

[48] J. D. Robertson, "Ionic regulation in the crab Carcinus maenas (L.) in relation to the moulting cycle," Comp. Biochem. Physiol., vol. 1, no. 3, pp. 183-212, 1960, doi: 10.1016/0010-406X(60)90023-2.

[49] J. R. STEVENSON, Dynamics of the Integument. ACADEMIC PRESS, INC., 1985.

[50] K. A. Keteles and J. W. Fleeger, "The contribution of 
ecdysis to the fate of copper, zinc and cadmium in grass shrimp, Palaemonetes pugio holthius," Mar. Pollut. Bull., vol. 42, no. 12, pp. 1397-1402, 2001, doi: 10.1016/S0025-326X(01)00172-2.

[51] J. J. Scott-Fordsmand and M. H. Depledge, "Changes in the tissue concentrations and contents of calcium copper and zinc in the shore crab Carcinus maenas (L.) (Crustacea: Decapoda) during the moult cycle and following copper exposure during ecdysis," Mar. Environ. Res., vol. 44, no. 4, pp. 397-414, 1997, doi: 10.1016/S0141-1136(97)00015-9.

[52] A. Shechter et al., "A gastrolith protein serving a dual role in the formation of an amorphous mineral containing extracellular matrix," Proc. Natl. Acad. Sci. U. S. A., vol. 105, no. 20, pp. 7129-7134, 2008, doi: 10.1073/pnas.0800193105.

[53] A. Shechter et al., "Reciprocal changes in calcification of the gastrolith and cuticle during the molt cycle of the red claw crayfish Cherax quadricarinatus," Biol. Bull., vol. 214, no. 2, pp. 122-134, 2008, doi: 10.2307/25066669.

[54] G. Luquet and F. Marin, "Biomineralisations in crustaceans: Storage strategies," Comptes Rendus Palevol, vol. 3, no. 6-7 SPEC.ISS., pp. 515-534, 2004, doi: 10.1016/j.crpv.2004.07.015.

[55] G. Luquet et al., "Calcium Deposits in the Crayfish, Cherax quadricarinatus: Microstructure Versus Elemental Distribution," Microsc. Microanal., vol. 22, no. 1, pp. 2238, 2016, doi: 10.1017/S1431927615015767.

[56] J. W. Hawkes and H. Schraer, "Mineralization during the molt cycle in Lirceus brachyurus (Isopoda: Crustacea) - I. Chemistry and light microscopy," Calcif. Tissue Res., vol. 12, no. 1, pp. 125-136, 1973, doi: 10.1007/BF02013728.

[57] F. Sardà, M. L. Cros, and B. Sesé, "Ca balance during moulting in the prawn Aristeus antennatus (Risso, 1816): the role of cuticle calcification in the life cycle of decapod crustaceans," J. Exp. Mar. Bio. Ecol., vol. 129, no. 2, pp. 161-171, 1989, doi: 10.1016/0022-0981(89)90054-3.

[58] D. O. Hessen, G. Kristiansen, and I. Lid, "Calcium uptake from food and water in the crayfish Astacus astacus (L., 1758), measured by radioactive $45 \mathrm{Ca}$ (Decapoda, Astacidea)," Crustaceana, vol. 60, no. 1, pp. 76-83, 1991.

[59] N. A. Rukke, "Effects of low calcium concentrations on two common freshwater crustaceans, Gammarus lacustris and Astacus astacus," Funct. Ecol., vol. 16, no. 3, pp. 357-366, 2002, doi: 10.1046/j.1365-2435.2002.00637.x.

[60] J. T. A. Dick, "The cannibalistic behaviour of two Gammarus species (Crustacea: Amphipoda)," J. Zool., vol. 236, no. 4, pp. 697-706, 1995, doi: 10.1111/j.14697998.1995.tb02740.x.

[61] R. L. France, "Calcium and trace metal composition of crayfish (Orconectes virilis) in relation to experimental lake acidification," Can. J. Fish. Aquat. Sci., vol. 44, no. SUPPL. 1, pp. 107-113, 1987, doi: 10.1139/f87-286.

[62] B. T. A. Muyssen, K. A. C. De Schamphelaere, and C. R. Janssen, "Calcium accumulation and regulation in Daphnia magna: Links with feeding, growth and reproduction," Comp. Biochem. Physiol. - A Mol. Integr. Physiol., vol. 152, no. 1, pp. 53-57, 2009, doi: 10.1016/j.cbpa.2008.08.031.

[63] F. P. Zanotto and M. G. Wheatly, "Calcium balance in crustaceans: Nutritional aspects of physiological regulation," Comp. Biochem. Physiol. - A Mol. Integr. Physiol., vol. 133, no. 3, pp. 645-660, 2002, doi: 10.1016/S1095-6433(02)00202-7.

[64] Y. Mazlum and S. Sirin, "The Effects of Using Different Levels of Calcium Carbonate $(\mathrm{CaCO} 3)$ on Growth, Survival, Molting Frequency and Body Composition of Freshwater Crayfish Juvenile, Pontastacus leptodactylus (Eschscholtz, 1823)," 2020.

[65] K. S. Hammond, J. W. Hollows, C. R. Townsend, and P. M. Lokman, "Effects of temperature and water calcium concentration on growth, survival and moulting of freshwater crayfish, Paranephrops zealandicus," Aquaculture, vol. 251, no. 2-4, pp. 271-279, 2006, doi: 10.1016/j.aquaculture.2005.05.032.

[66] J. Liang et al., "Effects of water temperature on the embryonic development, survival and development period of larvae of ridgetail white prawn (Exopalaemon carinicauda) reared in the laboratory," Shengtai Xuebao/ Acta Ecol. Sin., 2013, doi: 10.5846/stxb201204070485.

[67] S. P. Lall, "The Minerals," Fish Nutr., pp. 259-308, 2003, doi: 10.1016/b978-012319652-1/50006-9.

[68] S. Chanda, B. N. Paul, K. Ghosh, and S. S. Giri, "Dietary essentiality of trace minerals in aquaculture-A Review," Agric. Rev., vol. 36, no. 2, p. 100, 2015, doi: 10.5958/0976-0741.2015.00012.4.

[69] L. A. Roy, D. A. Davis, T. N. Nguyen, and I. P. Saoud, "Supplementation of chelated magnesium to diets of the pacific white shrimp, Litopenaeus vannamei, reared in low-salinity waters of West Alabama," J. World Aquac. Soc., vol. 40, no. 2, pp. 248-254, 2009, doi: 10.1111/j.1749-7345.2009.00247.x.

[70] K. R. Tavabe, G. Rafiee, M. Frinsko, and H. Daniels, "Effects of different calcium and magnesium concentrations separately and in combination on Macrobrachium rosenbergii (de Man) larviculture," Aquaculture, vol. 412-413, pp. 160-166, 2013, doi: 10.1016/j.aquaculture.2013.07.023.

[71] M. Jover, J. Fernández-Carmona, M. C. Del Río, and M. Soler, "Effect of feeding cooked-extruded diets, containing different levels of protein, lipid and carbohydrate on growth of red swamp crayfish (Procambarus clarkii)," Aquaculture, vol. 178, no. 1-2, pp. 127-137, 1999, doi: 10.1016/S0044-8486(99)001192.

[72] A. Paglianti and F. Gherardi, "Combined effects of temperature and diet on growth and survival of young-ofyear crayfish: A comparison between indigenous and invasive species," J. Crustac. Biol., vol. 24, no. 1, pp. 140-148, 2004, doi: 10.1651/C-2374.

[73] R. M. S. Schofield et al., "Br-rich tips of calcified crab claws are less hard but more fracture resistant: A comparison of mineralized and heavy-element biological materials," J. Struct. Biol., vol. 166, no. 3, pp. 272-287, 2009, doi: 10.1016/j.jsb.2009.01.007.

[74] M. Katsikini, "Detailed spectroscopic study of the role of $\mathrm{Br}$ and $\mathrm{Sr}$ in coloured parts of the Callinectes sapidus crab claw," J. Struct. Biol., vol. 195, no. 1, pp. 1-10, 2016, doi: 10.1016/j.jsb.2016.05.006.

[75] D. M. Smith and W. Dall, "Blood protein, blood volume 
and extracellular space relationships in two Penaeus spp. (decapoda: crustacea)," J. Exp. Mar. Bio. Ecol., vol. 63, no. 1, pp. 1-15, 1982, doi: 10.1016/0022-0981(82)900466.

[76] W. GHIDALIA, Structural and Biological Aspects of Pigments. ACADEMIC PRESS, INC., 1985.

[77] J. S. Djangmah and D. J. Grove, "Blood and hepatopancreas copper in crangon vulgaris (fabricus)," Comp. Biochem. Physiol., vol. 32, no. 4, pp. 733-745, 1970, doi: 10.1016/0010-406X(70)90824-8.

[78] A. Mohapatra, T. R. Rautray, A. K. Patra, V. Vijayan, and R. K. Mohanty, "Elemental composition in mud crab Scylla serrata from Mahanadi estuary, India: In situ irradiation analysis by external PIXE," Food Chem. Toxicol., 2009, doi: 10.1016/j.fct.2008.10.016.

[79] A. Mohapatra, T. R. Rautray, A. K. Patra, V. Vijayan, and R. K. Mohanty, "Trace element-based food value evaluation in soft and hard shelled mud crabs," Food Chem. Toxicol., vol. 47, no. 11, pp. 2730-2734, 2009, doi: 10.1016/j.fct.2009.07.037.

[80] G. Luquet et al., "Comparative ultrastructure and carbohydrate composition of gastroliths from astacidae, cambaridae and parastacidae freshwater crayfish (Crustacea, Decapoda)," Biomolecules, vol. 3, no. 1, pp. 18-38, 2013, doi: 10.3390/biom3010018.

[81] B. Y. J. N. Cameron, "Post-Moult Calcification in the Blue Crab, Callinectes Sapidus: Timing and Mechanism,"
J. Exp. Biol., vol. 143, no. 1, pp. 285-304, 1989.

[82] H. O. Fabritius, E. S. Karsten, K. Balasundaram, S. Hild, K. Huemer, and D. Raabe, "Correlation of structure, composition and local mechanical properties in the dorsal carapace of the edible crab cancer pagurus," Zeitschrift fur Krist., vol. 227, no. 11, pp. 766-776, 2012, doi: 10.1524/zkri.2012.1532.

[83] H. Fabritius, P. Walther, and A. Ziegler, "Architecture of the organic matrix in the sternal $\mathrm{CaCO} 3$ deposits of Porcellio scaber (Crustacea, Isopoda)," J. Struct. Biol., vol. 150, no. 2, pp. 190-199, 2005, doi: 10.1016/j.jsb.2005.01.004.

[84] H. Fabritius and A. Ziegler, "Analysis of $\mathrm{CaCO} 3$ deposit formation and degradation during the molt cycle of the terrestrial isopod Porcellio scaber (Crustacea, Isopoda)," J. Struct. Biol., vol. 142, no. 2, pp. 281-291, 2003, doi: 10.1016/S1047-8477(03)00030-3.

Creative Commons Attribution License 4.0 (Attribution 4.0 International ,CM3 BY 4.0)

This article is published under the terms of the Creative Commons Attribution License 4.0

https://creativecommons.org/licenses/by/4.0/deed.en_US 
INTERNATIONAL JOURNAL OF BIOLOGY AND BIOMEDICAL ENGINEERING

Table 1.Biometric data of S. paramamosain mud crab samples.

\begin{tabular}{lccc}
\hline \multirow{2}{*}{. paramamosain } & Life stages & Carapace width (CW) & Weight (BW) \\
\cline { 3 - 4 } & & $(\mathrm{cm})$ & $(\mathrm{g})$ \\
\hline Male & & $7.47 \pm 0.15$ & $79-90 \pm 13.2$ \\
\hline hard carapace & PreMolt & $8.57 \pm 0.23$ & $100-110 \pm 8.0$ \\
& PostMolt & $7.73 \pm 0.45$ & $81-87 \pm 10.4$ \\
soft carapace (exuvium) & InterMolt & $7.77 \pm 0.35$ & $98-106 \pm 2.5$ \\
\hline Female & Molt & & $76-80 \pm 5.5$ \\
Carapace hard & PreMolt & $7.13 \pm 0.29$ & $93-100 \pm 3.7$ \\
& PostMolt & $8.57 \pm 0.23$ & $75-80 \pm 7.1$ \\
Soft carapace (exuvium) & InterMolt & $7.27 \pm 0.50$ & $90-99 \pm 5.4$ \\
\hline
\end{tabular}

Table 2. Percentage by weight of various elements of $S$. paramamosain crab carapace (in wt $\%$ ) using the SEM-EDXS technique.

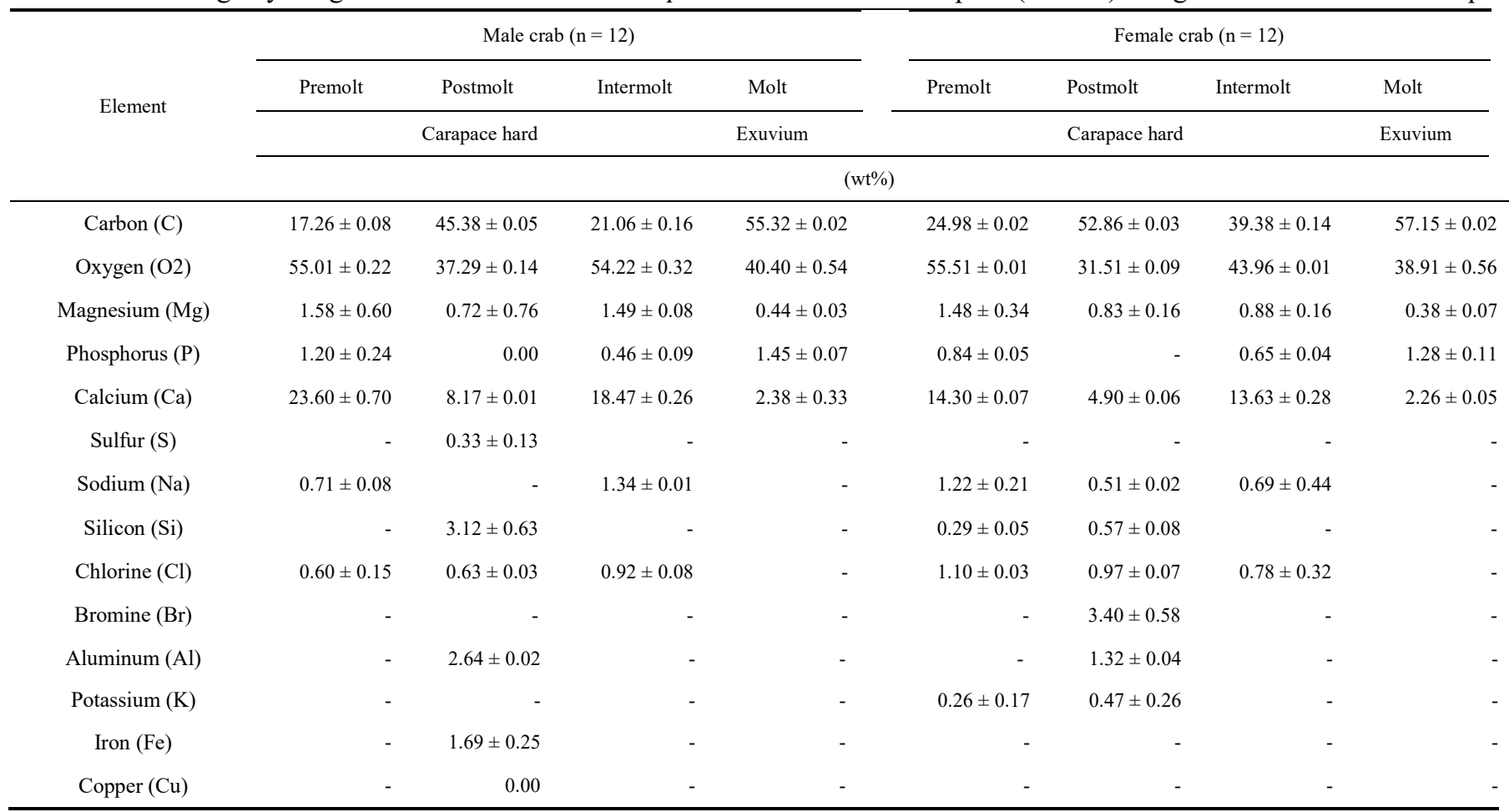




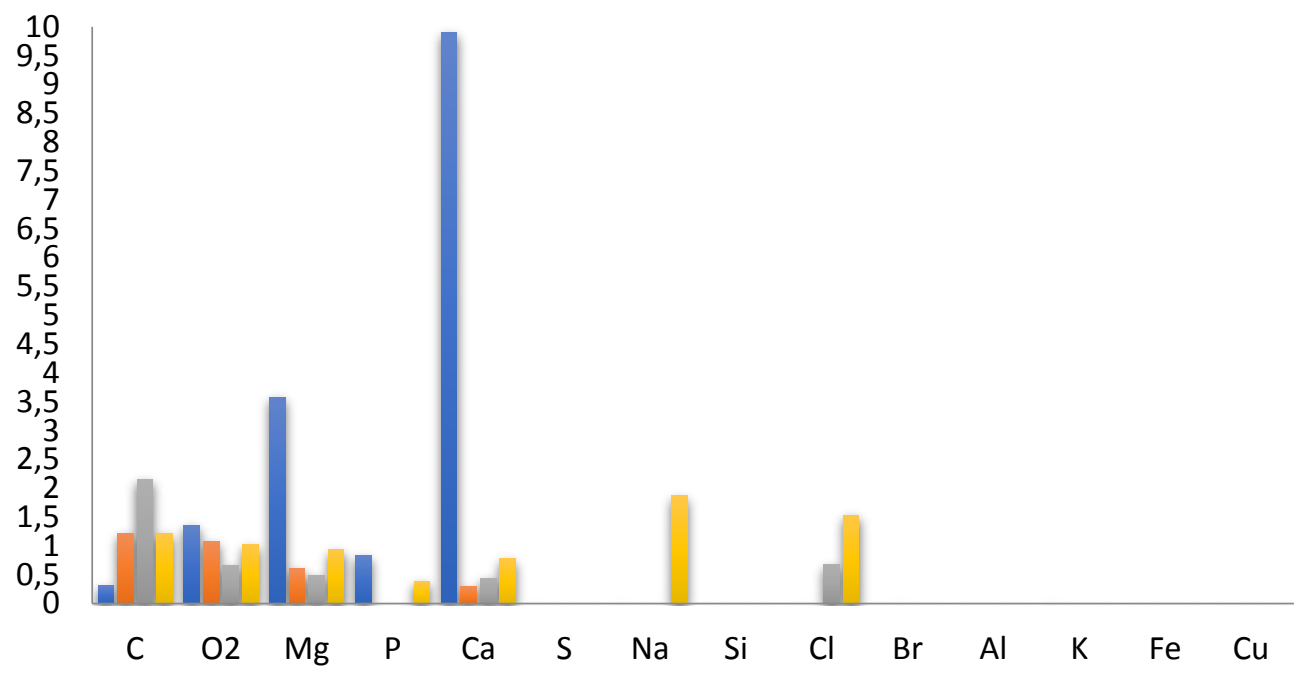

Premolt to molt $\square$ Molt to Postmolt $\square$ Postmolt to Intermolt $\square$ Intermolt to Premolt

Figure 1. Comparison of the elements in hard and soft carapace (exuvium) of male crab S. paramamosain

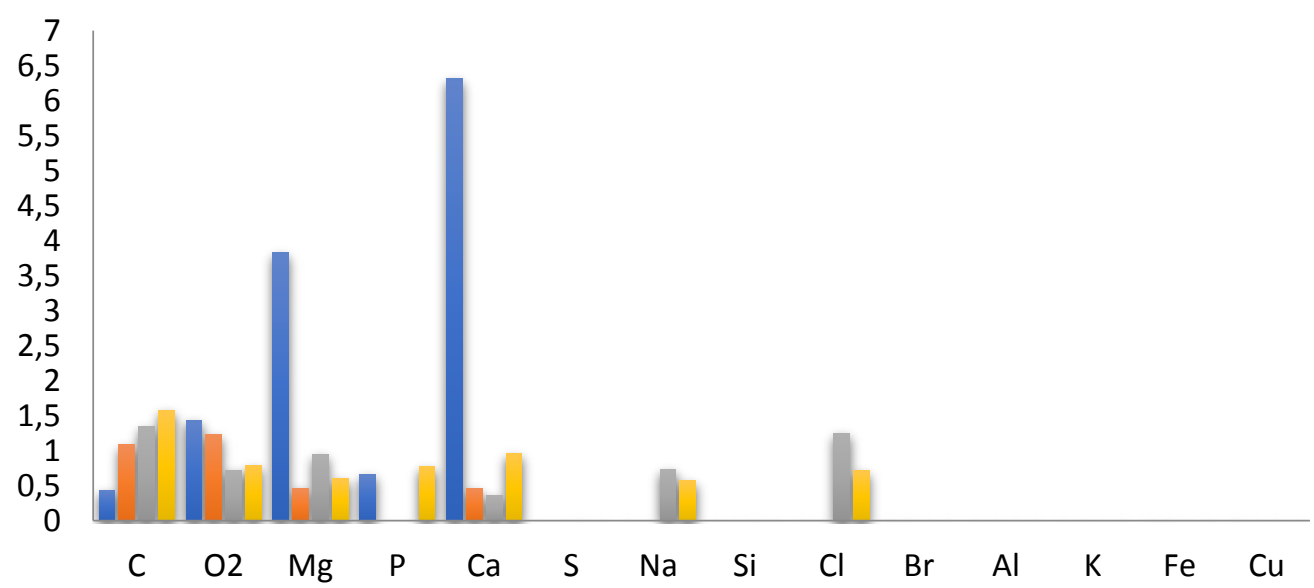

Premolt to molt $\square$ Molt to Postmolt $\square$ Postmolt to Intermolt $\square$ Intermolt to Premolt

Figure 2. Comparison of the elements in the hard and soft carapace (exuvium) of female $S$. paramamosain crabs 